\title{
PEMBERDAYAAN BUMDES DAN PELATIHAN KETRAMPILAN USAHA DIDESA SIDAKARYA DENPASAR BALI
}

\author{
Wayan Suryathi ${ }^{1}$, IB.Putu Suamba², Gede Pradiva Adiningrat 3 \\ 123Jurusan Administrasi Niaga Politeknik Negeri Bali \\ 1E-mail address wsuryathi2018@gmail.com, 2E-mail address suambaindiya@yahoo.com, \\ 3E-mail address gedepradiva@pnb.ac.id
}

\begin{abstract}
BUMDes of Sidakarya Village has a srtrategic role to help public society, however it enquare an empowerment because it the effort of management new years old, as well the community need intensif of training. The aim of community dedication are getting empowerment of BUMDes and give the effort skill training for people in Sidakarya Village. The acitivity of community dedication areTraditional cooking training, Business Ethic and digital communication. Partner targeting of this program are BUMDes, Karang Taruna and PKK of Sidakarya Vallage. The methode of this activity are training, focus group discussion, deept interview and questionare. The result and external target from the dedication are the empowerment of BUMDes has been reached and the skill of effort training has been action And obtained the value evaluation s very good
\end{abstract}

Key Words: Empowerment, Training, Skill, BUMDes

\section{Abstrak}

BUMDes Desa Sidakarya memiliki peran strategis untuk membantu perekonomian masyarakat, namun diperlukan suatu pemberdayaan karena manajemen usaha berusia baru setahun, demikian juga masyarakat perlu pelatihan secara intensif. Tujuan pengabdian masyarakat ini adalah memberdayakan BUMDes dan memberikan pelatihan ketrampilan usaha di Desa Sidakarya. Adapun bentuk pengabdian berupa pelatihan membuat kue tradisional, pembinaan etika bisnis dan komunikasi digitalisasi. Mitra sasaran program ini adalah BUMDes, kelompok Karang Taruna dan PKK Desa Sidakarya. Metode yang digunakan adalah pelatihan, fokus discussion group, deept interview dan kuisioner. Hasil dan target luaran dari kegiatan ini adalah tercapainya pemberdayaan Bumdes dan terlaksananya pelatihan ketrampilan dan diperoleh evaluasi penilaian dengan sangat baik

\section{Kata Kunci: Pemberdayaan, Pelatihan, Ketrampilan, BUMDes}

\section{PENDAHULUAN}

Desa Sidakarya merupakan salah satu bagian wilayah Kecamatan Denpasar Selatan yang berdiri secara definitif pada tanggal 1 Juni 1982, yang dikukuhkan berdasarkan Surat Keputusan Gubernur Kepala Daerah Tingkat I Bali Nomor 57 Tahun 1982. Desa Sidakarya terletak dipesisir selatan pulau Bali/Kota Denpasar dengan batas-batas kewilayahan sebagai berikut: Kelurahan Panjer dan Kelurahan Renon (Utara), Desa Sanur Kauh (Timur),Selat Badung (Selatan), Kelurahan 
Sesetan(Barat). Luas wilayah Desa Sidakarya lebih kurang 389 Ha, terdiri dari daratan lebih kurang 319 Ha, sawah lebih kurang 25 Ha, hutan bakau lebih kurang $45 \mathrm{Ha}$, tanah penggaraman lebih kurang $15 \mathrm{Ha}$, kini keberadaannnya secara mayoritas beralih fungsi sebagai bangunan pemukiman, tempat usaha dan lainnya.Desa Sidakarya terdiri dari dua belas (12) Dusun, dimana Pemerintahan Desa Sidakarya dipimpin oleh seorang Kepala Desa yang disebut Perbekel.

Berdasarkan uraian diatas maka mata pencaharian masyarakat pada umumnya sebagai pedagang dan bisnis hampir $80 \%$, sehingga potensi bisnis ini pada akhirnya memberikan ruang bagi BUMDes berdiri pada tahun 2018 di wilayah kantor desa sesuai anjuran pemerintah. Berdasarkan hasil survey dengan pengelola BUMDes dapat diperoleh informasi bahwa permasalahan yang dihadapi dari awal berdiri sampai saat ini adalah 1) modal usaha yang kecil, 2) rekanan usaha yang terbatas, 3) marketing usaha belum berkembang, 4) tingkat penjualan yang masih kecil dan terbatas. Dari empat masalah tersebut, maka masalah keempat yaitu penjualan yang masih kecil dan terbatas menjadi prioritas utama dari pelaksana dalam memberdayakan BUMDes Desa Sidakarya. Untuk mengatasi masalah ini diperlukan suatu upaya dan solusi yaitu memperkenalkan lebih luas keberadaan BUMDes Desa Sidakarya dikalangan masyarakat dalam bentuk mengadakan kerjasama kepada Kelompok Karang Taruna dan Posyandu, Ibu PKK Desa Sidakarya. Dengan kerjasama ini diharapkan hasil penjualan BUMDes akan meningkat dan mendatangkan keuntungan usaha. Badan Usaha Milik Desa yang selanjutnya disebut BUMDes adalah suatu lembaga/badan perekonomian desa yang berbadan hukum dibentuk dan dimiliki oleh Pemerintah Desa, dikelola secara ekonomis mandiri dan profesional dengan modal seluruhnya atau sebagian besar merupakan kekayaan desa yang dipisahkan (Amelia: 2014: 2). Harapan dengan adanya BUMDes, adalah pembentukan usaha baru yang berakar dari sumber daya yang ada serta optimalisasi kegiatan-kegiatan ekonomi masyarakat desa yang telah ada. Menurut Hasil kajian Robiatul (2018: 1) tujuan BUMDes yaitu mengoptimalkan pengelolaan aset-aset desa yang ada, memajukan perekonomian desa, serta meningkatkan kesejahteraan masyarakat desa. Corstya (2018:4) dengan kehadiran BUMDes ini diharapkan desa menjadi lebih mandiri dan masyarakatnya pun menjadi lebih sejahtera. Berdasarkan pendapat Edy (2016:4) dan Samadi (2015:1) tujuan dan sasaran BUMDes dapat tercapai jika BUMDes dikelola secara terarah dan professional melalui pemerataan, sehingga meningkatkan pendapatan masyarakat. 


\section{METODE DAN PELAKSANAAN}

\section{Metode}

Adapun bentuk metode yang digunakan dalam pengabdian masyarakat di Desa Sidakarya sebagai berikut: Metode Pelatihan, pendampingan, deept interview dan kuisioner. Evaluasi kegiatan dilakukan terhadap masing-masing peserta sesuai kegiatan dengan menggunakan rumus persentase $(\%)$ = skor yang diobservasi dibagi dengan skor yang diharapkan x 100\% dan kriteria penilaian didasarkan pada pendapat Sugiyono (2017:34), dimana ditentukan sebagai berikut: 1) $0-20 \%=$ Sangat tidak baik, 2) $21-40 \%=$ tidak baik, 3) $41-60 \%=$ Cukup, 4) $61-80 \%=$ Baik, 5) $81-100 \%=$ Sangat baik. Untuk lebih jelas dapat dilihat metode dan pelaksanaan kegiatan pengabdian masyarakat ini pada tabel 1 di bawah ini.

\section{Pelaksanaan Kegiatan}

Tabel 1. Metode dan Pelaksanaan Kegiatan

\begin{tabular}{|c|c|c|c|c|}
\hline $\mathrm{NO}$ & Waktu & $\begin{array}{c}\text { Bentuk dan Lokasi } \\
\text { Kegiatan }\end{array}$ & $\begin{array}{c}\text { Metode } \\
\text { pelaksanaan }\end{array}$ & $\begin{array}{l}\text { Jumlah } \\
\text { peserta/ } \\
\text { Latar belakang }\end{array}$ \\
\hline $\begin{array}{l}1 \\
2 \\
3 \\
4\end{array}$ & $\begin{array}{l}\text { Bulan Juni } 2020 \\
\text { Bulan Juli } 2020 \\
\text { Bulan Agustus 2020 } \\
\text { Bulan September 2020 }\end{array}$ & $\begin{array}{l}\text { Pelatihan usaha/ } \\
\text { Kewirausahaan di Dusun } \\
\text { Kerthasari } \\
\text { Pemberdayaan BUMDes di } \\
\text { Kantor Desa } \\
\text { Pelatihan Etika Bisnis dan } \\
\text { digital/Webinar di Kantor } \\
\text { Desa }\end{array}$ & \begin{tabular}{|l} 
Pelatihan dan \\
pendampingan \\
Focus Group Discussion \\
(FGD) \\
Deept Interview \\
Kuisioner
\end{tabular} & $\begin{array}{l}\text { 15-32 orang/ } \\
\text { Peserta berasal dari } \\
\text { kelompok karang } \\
\text { taruna, pkk dan } \\
\text { posyandu }\end{array}$ \\
\hline
\end{tabular}

Sumber : Data diolah

Dari tabel 1 dapat diketahui bahwa waktu pelaksanaan program berlangsung selama 4 bulan dari bulan Juni, Juli, Agustus dan September 2020 yang mana terdapat tiga bentuk kegiatan yaitu pelatihan kewirausahaan, Pemberdayaan BUMDes dan pelatihan digital webinar.Jumlah peserta sebanyak 32 orang.

\section{HASIL DAN PEMBAHASAN}

\section{a. Hasil Kegiatan}

Berdasarkan program kerja kegiatan pengabdian masyarakat di Desa Sidakarya maka realisasi kegiatan yang dapat dilaksanakan yaitu:

1) Mengadakan pelatihan dan pendampingan ketrampilan potensi usaha Karang Taruna, PKK dan Posyandu dengan tema melestarikan kue tradisionil kepada generasi muda di Desa Sidakarya Denpasar, hal ini dalam rangka pemberdayaan BUMDes dengan adanya jalinan kerjasama pemanfaatan produk dan jasa 
yang dijual sebagai sarana prasarana kepada kelompok peserta, selain itu diupayakan memberikan pendampingan praktik penjualan via online dimasa pandemi ini.

2) Mengadakan praktik webinar dan digitalisasi dengan tema pemahaman etika bisnis dan perlindungan kepada BUMDes dan UKM/UMKM dimasa pandemi masyarakat Desa Sidakarya Denpasar. Praktik digitalisasi berbentuk webinar yang melibatkan Dosen Politeknik Negeri Bali, Kepala Desa Sidakarya, Karang Taruna, PKK, Kelompok Sekehe Kuliner Bali, BumDes Desa Sidakarya.

\section{b. Evaluasi Kegiatan}

Berdasarkan hasil deept interview dan kuisioner terhadap 32 peserta kegiatan pelatihan dan pendampingan praktik kegiatan pengabdian masyarakat di Desa Sidakarya Denpasat dapat dijelaskan evaluasi target capaian pada tabel 2 di bawah ini:

Tabel 2. Evaluasi Penilaian Peserta Pengabdian

\begin{tabular}{|c|c|c|c|c|c|c|}
\hline \multirow{2}{*}{$\frac{\text { No }}{1}$} & Program Kegiatan & \multicolumn{5}{|c|}{ Penilaian Peserta } \\
\hline & $\begin{array}{l}\text { Pelatihan Ketrampilan } \\
\text { Usaha Kue Tradisional } \\
\text { Bali }\end{array}$ & $\begin{array}{l}\text { Jumlah } \\
\text { peserta } \\
\text { (orang) }\end{array}$ & $\begin{array}{l}\text { Tidak } \\
\text { setuju }\end{array}$ & Setuju & Persentase & Kriteria \\
\hline & $\begin{array}{l}\text { Waktu pelatihan sesuai } \\
\text { jadwal, pelatih } \\
\text { profesional, } \\
\text { materi latihan sangat } \\
\text { berguna menambah } \\
\text { ketrampilan sarana dan } \\
\text { alat pelatihan tersedia } \\
\text { lengkap, serta } \\
\text { pelatihan perlu dilanjut } \\
\text { kan dimasa mendatang }\end{array}$ & 32 & 0 & 32 & 100 & $\begin{array}{l}\text { Sangat } \\
\text { Baik }\end{array}$ \\
\hline 2 & $\begin{array}{l}\text { Webinar Etika bisnis dan } \\
\text { pemberdayaan Bumdes }\end{array}$ & & & & & \\
\hline & $\begin{array}{l}\text { Webinar pemahaman } \\
\text { etika bisnis memberikan } \\
\text { wawasan baru,webinar } \\
\text { membantu peningkatan } \\
\text { kemampuan komunikasi } \\
\text { digitalisasi,webinar } \\
\text { mampu meningkatkan } \\
\text { pemberdayaan dan } \\
\text { kerjasama BUMDes }\end{array}$ & 15 & $\mathrm{o}$ & 15 & 100 & $\begin{array}{l}\text { Sangat } \\
\text { Baik }\end{array}$ \\
\hline
\end{tabular}

Dari tabel 2 di atas dapat diketahui bahwa penilaian peserta sangat baik terhadap kegiatan pengabdian masayarakat di Desa Sidakarya berkaitan dengan pemberdayaan BUMDes dan Webinar Etika Bisnis. Dokumentasi kegiatan pengabdian dapat dilihat pada gambar 1.gambar 2, gambar 3 di bawah ini. 


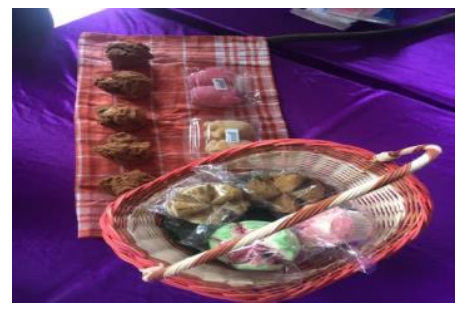

Gambar 1. Jenis kue Tradisional Bali

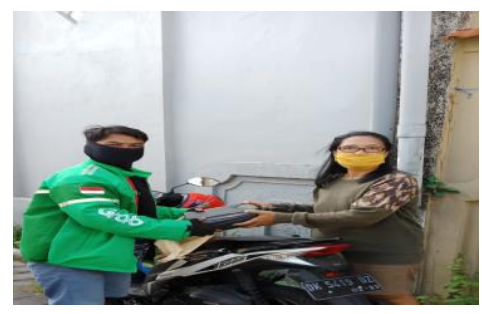

Gambar 2. Etika Bisnis Digitalisasi

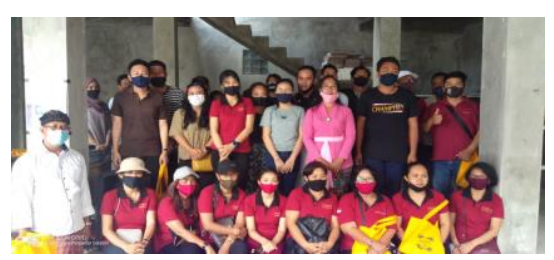

Gambar 3. Peserta pelatihan di Desa Sidakarya

\section{PENUTUP}

\section{Simpulan}

Berdasarkan uraian hasil realisasi kegiatan dan target luaran di atas dapat disimpulkan bahwa pelaksanaan pengabdian masyarakat Di Desa Sidakarya dapat berjalan dengan lancar dan sangat baik, karena mendapat apresiasi dari peserta Karang taruna. Kegiatan pengabdian terdiri dari 2 program yaitu pelatihan potensi usaha pembuatan kue tradisional Bali dalam rangka pemberdayaan BUMDes dan pemahaman etika bisnis dan praktik digitalisasi melalui Webinar. Peserta memberikan kesan dan pesan yang sangat baik, mereka antusias dan mengapresiasi dengan adanya pelatihan tersebut. Namun kekurangan dari kegiatan ini adalah keterbatasan waktu pelaksanaan, sehingga peserta yang terlibat hanya satu dusun dari dua belas dusun yang ada di Desa Sidakarya.

\section{Saran}

Peserta menyatakan perlu dilatih dan diberikan penambahan ketrampilan yang sama pada masa mendatang, juga kesan dari pihak Kepala Desa dan BUMDes memberikan kesan yang baik untuk melanjutkan kerjasama pengabdian masyarakat ini.

\section{Ucapan Terima Kasih}

Kami mengucapkan terima kasih kepada Bapak Direktur PNB, Bapak Kepala P3M PNB, Bapak Kepala Desa Sidakarya dan rekan-rekan tim pengabdian atas kerjasamanya dan dukungannya selama kegiatan ini berjalan. 


\section{DAFTAR PUSTAKA}

Amelia Sri Kusuma Dewi. 2014. Peranan Badan Usaha Milik Desa (BUMDes) Sebagai Upaya Dalam Meningkatkan Pendapatan Asli Desa (PADes) Serta Menumbuhkan Perekonomian Desa. Journal Of Rural And Development.1(1),1-14.

Robiatul Adawiyah. 2018. Strategi Pengembangan Badan Usaha Milik Desa (BUMDes Berbasis Aspek Modal Sosial (Studi pada BUMDes Surya Sejahtera, Desa Kedungturi, Kecamatan Taman, Kabupaten Sidoarjo). Jurnal Kebijakan Dan Manajemen Publik 6(3).1-15.

Coristya Berlian Ramadana, Heru Ribawanto dan Suwondo. 2018.Keberadaan Badan Usaha Milik Desa (BUMDes) Sebagai Penguatan Ekonomi Desa (Studi di Desa Landungsari, Kecamatan Dau, Kabupaten Malang). Jurnal Administrasi Publik (JAP), 1(6),1068-1076.

Edy Yusuf Agunggunanto, Fitrie Arianti dan Edi Wibowo. 2016. Pengembangan Desa Mandiri Melalui Pengelolaan Badan Usaha Milik Desa (BUMDes). Jurnal Dinamika Ekonomi dan Bisnis,13(1),1-15.

Samadi, Arrafigur Rahmana Afrizal. 2015. Peranan BUMDes dalam Peningkatan Ekonomi (Studi pada BUMDes Desa Pekan Lebih. E-Jurnal Mahasiswa Prodi Manajemen, 2(1),1-19.

Sugiyono. 2017. Metode Penelitian Kuantitatif , Kualitatif dan R\&D. Bandung : Alfabeta

\section{Link Artikel}

https://drive.google.com/file/d/1Qg44hje2gbph34QsoOuYbIUS7b4CyHH/view?usp=sharing 